\title{
ANALISIS SWOT KONVERSI KOPERASI KONVENSIONAL KE KOPERASI SYARIAH DI KOTA PADANG PANJANG
}

\author{
Rozi $^{1)^{*}}$, Zainuddin ${ }^{2)}$, Hendra Yuharmain ${ }^{3)}$ \\ 1)233** Pascasarjana Institut Agama Islam Negeri Batusangkar, Batusangkar, Indonesia \\ Email: rrajoameh@gmail.com
}

\begin{abstract}
The main problem in this research is how to implement the conversion of conventional cooperatives to sharia cooperatives in Padang Panjang City. The purpose of this study was to conduct a SWOT analysis in the implementation of the conversion of conventional cooperatives to sharia cooperatives in Padang Panjang City. The type of research that the author does is field research with a qualitative approach, namely exploring the phenomena interpretively related to the strengths, weaknesses, opportunities, and challenges of the conversion of conventional cooperatives to sharia cooperatives in Padang Panjang City. The results show that the implementation of the conversion of conventional cooperatives to sharia cooperatives has greater strength than the weakness factor, so that sharia cooperatives in the City of Padang Panjang have great strength for their development, and the implementation of the conversion of conventional cooperatives to sharia cooperatives has a greater opportunity than the other factors threat.
\end{abstract}

Keywords: SWOT analysis, conversion, sharia cooperative.

ABSTRAK: Masalah utama dalam penelitian ini adalah bagaimana implementasi konversi koperasi konvensional menjadi koperasi syariah di Kota Padang Panjang. Tujuan dari penelitian ini adalah untuk melakukan analisis SWOT dalam pelaksanaan konversi koperasi konvensional menjadi koperasi syariah di Kota Padang Panjang. Jenis penelitian yang penulis lakukan adalah penelitian lapangan dengan pendekatan kualitatif yaitu menggali fenomena secara interpretatif terkait dengan kekuatan, kelemahan, peluang, dan tantangan konversi koperasi konvensional menjadi koperasi syariah di Kota Padang Panjang. Hasil penelitian menunjukkan bahwa implementasi konversi koperasi konvensional ke koperasi syariah memiliki kekuatan yang lebih besar daripada faktor kelemahan, sehingga koperasi syariah di Kota Padang Panjang memiliki kekuatan yang besar untuk perkembangannya, dan implementasi konversi koperasi konvensional ke Koperasi syariah memiliki peluang yang lebih besar dibandingkan dengan faktor ancaman lainnya.

Kata Kunci: analisis SWOT, konversi, koperasi syariah

\section{A. PENDAhULUAN}

Indonesia sebagai negara dengan jumlah penduduk muslim terbesar, tidak terlepas dari pengaruh perkembangan ekonomi syariah yang cukup pesat pada beberapa dasawarsa terakhir. Hal ini disebabkan karena sistem ekonomi Islam berbeda dengan sistem ekonomi yang lain. Ekonomi Islam tidak hanya bertujuan pada aspek materi saja, tetapi luas daripada itu yang meliputi aspek kemakmuran, kehidupan yang lebih baik, persaudaran, dan dimensi iman pada setiap urusan manusia (Nabhan, 2000). Sehingga sistem ekonomi Islam dapat dijadikan sebagai suatu solusi untuk menyelesaikan persoalan ekonomi Indonesia (Iska, 2019).

Sistem ekonomi Islam yang semakin berkembang tersebut, tidak terlepas dari meningkatnya pemahaman masyarakat tentang haramnya riba. Haramnya riba tidak hanya ada dalam ajaran Islam, termasuk dalam ajaran agama-agama samawi yang lain, riba dipandang sebagai praktik eksploitatif, reduktif, dan destruktif sehingga mendapat kecaman dan larangan yang keras dari berbagai kelompok yang menentangnya (Nofendy, 2020). Hal 
inilah yang sangat berpengaruh terhadap munculnya berbagai lembaga keuangan syariah, baik yang berupa bank dan non bank. Lembaga keuangan syariah non bank, diantaranya berwujud koperasi syariah, yaitu Koperasi Jasa Keuangan Syariah dan Koperasi Simpan Pinjam Pembiayaan Syariah (Fitria, 2016).

Secara prinsip, koperasi merupakan gerakan ekonomi rakyat yang bersifat gotong royong yang mempunyai maksud untuk mewujudkan masyarakat yang maju, adil dan makmur, sebagaimana yang dicita-citakan Undang-Undang Dasar Tahun 1945 pada Pasal 33 ayat (1), dinyatakan bahwa perekonomian disusun sebagai usaha bersama berdasarkan atas asas kekeluargaan. Dasar konstitusi ini sebagai pijakan hukum bagi pengembangan dunia koperasi di Indonesia dalam mewujudkan kemandirian ekonomi yang menekankan pada pada usaha bersama (partisipasi) anggota serta azas kekeluargaan (Buchori et al., 2019).

Menyikapi tuntutan akan payung hukum dalam pembinaan koperasi di Indonesia dan sebagai respon terhadap perkembangan koperasi syariah, telah ditetapkan Keputusan Menteri Negara Koperasi dan Usaha Kecil dan Menengah Nomor 91/Kep/M.KUKM/IX/2004 tentang Petunjuk Pelaksanaan Kegiatan Usaha Koperasi Jasa Keuangan Syariah. Dengan ditetapkannya keputusan ini, keberadaan koperasi syariah di Indonesia bisa dipertanggungjawabkan status hukumnya, mengingat sebelumnya belum ada kebijakan dan regulasi yang khusus mengatur koperasi syariah di Indonesia (Sofiana, 2014).

Political will dalam mewujudkan koperasi syariah sebagai badan usaha yang bersifat formal dan meningkatkan pertumbuhan koperasi syariah, juga dilahirkannya beberapa produk hukum yang mengatur koperasi syariah. Untuk tingkat daerah, Pemerintah Provinsi Sumatera Barat juga menindaklanjuti dengan Keputusan Gubernur Sumatera Barat Nomor 516-451-2018 tentang Pembentukan Tim Percepatan Pengembangan Koperasi Syariah di Sumatera Barat.

Kebijakan pada tingkat provinsi tersebut juga ditindaklanjuti oleh Pemerintah Kota Padang Panjang, dengan menetapkan koperasi syariah sebagai salah satu pilar dalam pengembangan ekonomi masyarakatnya. Hal tersebut diimplementasikan dalam visi dan misi Walikota Padang Panjang Tahun 2018-2023 sebagaimana diatur dalam Perda Kota Padang Panjang Nomor 2 Tahun 2019 tentang Rencana Pembangunan Jangka Menengah Daerah Tahun 2018-2023. Dalam Perda tersebut dinyatakan bahwa salah satu kebijakan dalam mewujudkan perkembangan ekonomi unggulan daerah yang berdasarkan pembangunan berkelanjutan, yaitu meningkatkan peran koperasi syariah dalam pengembangan ekonomi.

Salah satu faktor yang mendorong Pemerintah Kota Padang Panjang menetapkan kebijakan peningkatan peran koperasi syariah dalam pengembangan ekonomi adalah dalam rangka memenuhi kebutuhan masyarakat di bidang usaha simpan pinjam yang dilaksanakan dengan pola pelayanan berdasarkan prinsip ekonomi syariah, dan mewujudkan peningkatan pembiayaan peran koperasi syariah bagi usaha kecil dan menengah di Kota Padang Panjang.

Kebijakan Pemerintah Kota Padang Panjang tersebut, tidak terlepas dari julukan Kota Padang Panjang sebagai kota Serambi Mekah, yaitu suatu kota dimana masyarakatnya sangat kental dengan pelaksanaan syariat Islam, yang terlihat dari akhlak masyarakatnya. Selain itu Kota Padang Panjang merupakan kota pendidikan Islam sejak akhir abad ke 20, yaitu dengan berdirinya Sumatera Thawalib, Thawalib Gunung, Diniyah Puteri, dan Kauman Muhammadiyah (Sufyan, 2018).

Sejak ditetapkannya Keputusan Walikota Padang Panjang Nomor 25 Tahun 2019 tentang Tim Percepatan Pengembangan Koperasi Syariah di Kota Padang Panjang pada tanggal 2 Februari 2019, sampai pada awal tahun 2021, dari 48 (empat puluh delapan) koperasi yang aktif di Kota Padang Panjang, baru 1 (satu) koperasi yang telah berbadan hukum sebagai koperasi syariah yakni Koperasi Pegawai Negeri Balaikota Padang Panjang. Sedangkan, 20 (dua puluh) koperasi sedang proses konversi ke syariah, dimana koperasi tersebut telah melalui persetujuan anggota (RAT) dan proses transisi kegiatan usaha ke syariah, namun belum berbadan hukum sebagai koperasi syariah. Selain itu, terdapat 5 
koperasi yang telah melaksanakan persetujuan anggota untuk konversi ke syariah (RAT), namun belum melaksanakan proses transisi kegiatan usaha ke syariah.

Tabel 1

Daftar Koperasi Proses Konversi ke Syariah di Kota Padang Panjang

\begin{tabular}{|c|c|c|}
\hline No & Nama Koperasi & Alamat \\
\hline \multicolumn{3}{|c|}{ Koperasi yang telah melaksanakan persetujuan RAT dan proses transisi ke syariah } \\
\hline 1 & KSPPS ISI PADANG PANJANG & Kelurahan Guguk Malintang \\
\hline 2 & KPRI SERAMBI MEKAH & Kelurahan Silaing Bawah \\
\hline 3 & KSU SEHATI & Kelurahan Tanah Hitam \\
\hline 4 & KPN SLTP 1 & Kelurahan Balai-Balai \\
\hline 5 & KPRI MAN KOTO BARU & Komplek MAN Koto Baru \\
\hline 6 & KPRI SMUN 2 & Kelurahan Guguk Malintang \\
\hline 7 & KOPKAR YARSI & Kelurahan Bukit Surungan \\
\hline 8 & KPRI RSUD & Kelurahan Ganting \\
\hline 9 & KPRI SMPN 3 & Keurahan. Ekor Lubuk \\
\hline 10 & KPRI SMA N 1 & Kelurahan Guguk Malintang \\
\hline 11 & KPRI SEDAR & Kelurahan Guguk Malintang \\
\hline 12 & KPN SMP N 2 & Kelurahan Guguk Malintang \\
\hline 13 & KPN KOKANDIKO & Kelurahan Guguk Malintang \\
\hline 14 & KPRI SMK 1 & Kelurahan Guguk Malintang \\
\hline 15 & KPRI SMPN 4 & Kelurahan Silaing Atas \\
\hline 16 & KPRI KOPRIDA DEPAG & Kelurahan Tanah Pak Lambik \\
\hline 17 & KPRI MTSN & Kelurahan Bukit Surungan \\
\hline 18 & KOP. PERGURUAN THAWALIB & Kelurahan Bukit Surungan \\
\hline 19 & KOPERASI KARYAWAN PDAM & Kelurahan Pasar Usang \\
\hline 20 & KOPPONTREN DINIYAH PUTRI & Kelurahan Pasar Usang \\
\hline \multicolumn{3}{|c|}{$\begin{array}{l}\text { Koperasi yang telah melakukan persetujuan anggota (RAT) namun belum melakukan } \\
\text { proses transisi ke syariah }\end{array}$} \\
\hline 1 & KSP KENCANA & Kelurahan Pasar Usang \\
\hline 2 & KPN KOPESDA & Kelurahan Guguk Malintang \\
\hline 3 & KSU AMAL HUSNA & Kelurahan Pasar Usang \\
\hline 4 & KSP SAIYO SAKATO & Kelurahan Pasar Baru \\
\hline 5 & KPN RUTAN & Kelurahan Tanah Pak Lambik \\
\hline
\end{tabular}

Sumber : Dinas Perdagangan, Koperasi, Usaha Kecil dan Menengah Kota Padang Panjang, 2021

Tabel 2

Daftar Koperasi yang Belum Melakukan Proses Konversi ke Syariah di Kota Padang Panjang

\begin{tabular}{|c|l|l|}
\hline No & \multicolumn{1}{|c|}{ Nama Koperasi } & \multicolumn{1}{c|}{ Alamat } \\
\hline 1 & KOPKAR POS DAN GIRO & Kelurahan Pasar Usang \\
\hline 2 & KPN PENGADILAN NEGERI & Kelurahan Bukit Surungan \\
\hline 3 & KOPPAS AIPT & Kelurahan Pasar Baru \\
\hline 4 & KOPPAS SAMUDERA & Kelurahan Balai-Balai \\
\hline 5 & KSP WARTA & Kelurahan Silaing Bawah \\
\hline 6 & KOPWAN MELATI & Kelurahan Silaing Bawah \\
\hline 7 & PRIMKOPABRI & Kelurahan Pasar Usang \\
\hline 8 & KSU AKU & Kelurahan Pasar Usang \\
\hline
\end{tabular}




\begin{tabular}{|l|l|l|}
\hline 9 & KSP SAIYO SAKATO & Kelurahan Pasar Baru \\
\hline 10 & $\begin{array}{l}\text { KOPERASI JASA KARYA } \\
\text { MANDIRI LESTARI }\end{array}$ & Kelurahan Silaing Bawah \\
\hline 11 & KPN KEJAKSAAN & Kelurahan Guguk Malintang \\
\hline 12 & KPN KARYATAMA & Kelurahan Ngalau \\
\hline 13 & KPN MAN GUNUNG & Kelurahan Ganting \\
\hline 14 & KSP MAKMUR & Kelurahan Ngalau \\
\hline 15 & KSP KENCANA & Kelurahan Pasar Usang \\
\hline 16 & KPSP MERSI & Kelurahan Ganting \\
\hline 17 & KSU SMK II & Kelurahan Ganting \\
\hline 18 & PRIMKOPAD SECATA B & Kelurahan Guguk Malintang \\
\hline 19 & PRIMKOPOL RESORT & Kelurahan Koto Panjang \\
\hline 20 & KSU SEAYUN SELANGKAH & Kelurahan Tanah Pak Lambik \\
\hline 21 & KUD MADYA & Kelurahan Ngalau \\
\hline 22 & KPN SEHAT & Kelurahan Kampung Manggis \\
\hline 23 & KSU MADANIY & Kelurahan Guguk Malintang \\
\hline
\end{tabular}

Sumber : Dinas Perdagangan, Koperasi, Usaha Kecil dan Menengah Kota Padang Panjang, 2021

Berdasarkan tabel diatas, perkembangan koperasi syariah di Kota Padang Panjang belum menunjukan perkembangan yang signifikan. Hal ini dapat dilihat dari persentase jumlah koperasi yang telah melaksanakan persetujuan anggota dan melaksanakan proses syariah di Kota Padang Panjang baru mencapai 21 (dua puluh satu) koperasi dari 48 (empat puluh delapan) koperasi yang aktif di Kota Padang Panjang atau $44 \%$ (empat puluh empat perseratus) dari jumlah koperasi yang ada.

Apabila dilihat dari target Rencana Pembangunan Jangka Menengah Daerah Kota Padang Panjang Tahun 2018-2023, dimana target capaian pada tahun 2021 ditetapkan sebesar $62,25 \%$ (enam puluh dua koma dua lima perseratus) atau mencapai 30 (tiga puluh) koperasi. Kondisi tersebut tentu masih jauh dari target pengembangan koperasi syariah di Kota Padang Panjang. Untuk itu, menjadi kewajiban Pemerintah Kota Padang Panjang untuk memfasilitasi pelaksanaan konversi ke syariah terhadap koperasi konvensional yang ada, dalam rangka pencapaian visi dan misi Walikota Padang Panjang Tahun 2018-2023. Sehingga koperasi yang belum melakukan konversi ke syariah yang berjumlah 27 (dua puluh tujuh) koperasi dapat melaksanakan proses konversi dan transisi ke syariah pada tahun 2023.

Kebijakan Pemerintah Kota Padang Panjang untuk melakukan konversi koperasi konvensional ke Koperasi Syariah merupakan keputusan yang strategis, yang tidak hanya berpengaruh terhadap perubahan produk dan sistem, namun juga kepada pelayanan yang diberikan kepada masyarakat, dan pelaksanaan pekerjaan oleh karyawan koperasi atau budaya kerjanya, serta perubahan yang signifikan terhadap laporan keuangan serta pendapatan yang berbeda dari konvensional. Kebijakan ini menarik untuk dikaji dan diteliti untuk melihat peluang pengembangan konversi koperasi syariah di Kota Padang Panjang.

Dalam penelitian ini akan dilakukan analisa lebih mendetail melalui analisis strength, weakness, oppurtunity, threats (SWOT) terhadap konversi koperasi syariah. Dengan alat analisis SWOT akan dilakukan identifikasi berbagai faktor secara sistematis sehingga menghasilkan suatu strategi bagi Pemerintah Kota Padang Panjang dalam rangka pencapaian tujuan sebagaimana tercantum dalam visi dan misi Walikota Padang Panjang Tahun 2018-2023 (Rangkuti, 1998). 


\section{B. METODE PENELITIAN}

\section{Jenis Penelitian}

Jenis penelitian ini adalah penelitian lapangan dengan memakai pendekatan kualitatif yakni mendalami tentang fenomena secara interpretatif terkait dengan peluang, tantangan, kekuatan, dan kelemahan terhadap konversi koperasi konvensional ke koperasi Syariah di Kota Padang Panjang.

\section{Tempat dan Waktu Penelitian}

Penelitian ini penulis lakukan di Kota Padang Panjang, yang dilakukan pada koperasi yang telah melaksanakan proses konversi ke syariah di Kota Padang Panjang dengan jumlah 22 (dua puluh dua) koperasi, yang dimulai sejak bulan Mei 2021 sampai dengan bulan Juni 2021. Adapun koperasinya adalah sebagai berikut:

1. Koperasi Pegawai Negeri Balaikota Padang Panjang;

2. Koperasi Simpan Pinjam dan Pembiayaan Syariah Institut Seni Indonesia Padang Panjang;

3. Koperasi Pondok Pesantren Diniyah Putri;

4. Koperasi Pegawai Republik Indonesia Serambi Mekah;

5. Koperasi Serba Usaha SEHATI;

6. Koperasi Pegawai Negeri SLTP 1;

7. Koperasi Pegawai Republik Indonesia MAN Koto Baru;

8. Koperasi Pegawai Republik Indonesia SMU N 2;

9. Koperasi Karyawan YARSI;

10. Koperasi Pegawai Republik Indonesia RSUD;

11. Koperasi Pegawai Republik Indonesia SMPN 3;

12. Koperasi Pegawai Republik Indonesia SMAN 1;

13. Koperasi Pegawai Republik Indonesia SEDAR;

14. Koperasi Pegawai Republik Indonesia SMPN 2;

15. Koperasi Pegawai Republik Indonesia KOKANDIKO;

16. Koperasi Pegawai Republik Indonesia SMK 1;

17. Koperasi Pegawai Republik Indonesia SMPN 4;

18. Koperasi Pegawai Republik Indonesia KOPRIDA DEPAG;

19. Koperasi Pegawai Republik Indonesia MTSN;

20. Koperasi Perguruan Thawalib;

21. Koperasi Karyawan PDAM; dan

22. KSP Kencana.

\section{Teknik Analisis Data}

Teknik analisis data yang penulis pakai adalah dengan menggunakan analisis SWOT. Dimana analisis SWOT ini adalah singkatan dari strengths (kekuatan), weaknesses (kelemahan), opportunities (peluang), dan threats (ancaman). Dalam menggunakan teknik SWOT gagasan dan pendapat-pendapat narasumber dikumpulkan melalui hasil wawancara, telepon atau tatap muka, kemudian menulis daftar kekuatan, kelemahan, peluang, dan ancaman. Setelah mengetahui informasi dari pihak terkait langkah selanjutnya adalah sebagai berikut:

1. Menyusun dan menentukan faktor-faktor strategis eksternal dan internal konversi ke syariah koperasi-koperasi di Kota Padang Panjang (Fahmi, 2013).

2. Menganalisis dan menentukan keputusan strategis dengan pendekatan matrik SWOT secara kualitatif dengan mengandalkan analisis kekuatan narasi yang sistematis dan interpretative. 
Diagram 1

Matrik SWOT

\begin{tabular}{|c|c|c|}
\hline & $\begin{array}{c}\text { Strengths }(\mathrm{S}) \\
\text { (Kekuatan) }\end{array}$ & Threats (T) (Kelemahan) \\
\hline $\begin{array}{c}\text { Opportunities }(\mathrm{O}) \\
\text { (Peluang) }\end{array}$ & Strategi untuk SO & Strategi untuk WO \\
\hline $\begin{array}{c}\text { Weaknesses }(\mathrm{W}) \\
\text { (Ancaman }\end{array}$ & Strategi untuk ST & Strategi untuk WT \\
\hline
\end{tabular}

Sumber : (Fahmi, 2013)

a. (Kekuatan, kesempatan atau S, O) artinya Pemerintah Kota Padang Panjang menetapkan strategi dengan mengkombinasikan kekuatan dan kesempatan yang bisa memanfaatkan kekuatan untuk menggunakan peluang sebaik-baiknya.

b. (Kelemahan, kesempatan atau W, O) artinya Pemerintah Kota Padang Panjang menetapkan strategi bagaimana meminimalkan kelemahan yang selalu muncul dalam perusahaan dengan memanfaatkan peluang yang menguntungkan.

c. (Kekuatan, ancaman atau S, T) artinya Pemerintah Kota Padang Panjang bisa memanfaatkan kekuatan baik dalam hal manajemen, sistem pemasaran maupun kemampuan finansial untuk mengatasi ancaman.

d. (Kelemahan, Ancaman atau W, T) artinya Pemerintah Kota Padang Panjang harus meminimalkan kelemahan dan menghindari ancaman.

\section{HASIL DAN PEMBAHASAN}

\section{Analisis SWOT Konversi Koperasi Konvensional ke Koperasi Syariah di Kota Padang Panjang}

Berdasarkan hasil wawancara penulis dengan informan, maka analisis faktor internal dan faktor eksternal pelaksanaan konversi koperasi konvensional ke koperasi syariah di kota padang panjang adalah sebagai berikut:

1. Faktor internal konversi koperasi konvensional ke koperasi syariah di Kota Padang Panjang

Faktor internal ini merupakan faktor yang berasal dari dalam koperasi itu sendiri yang akan mempengaruhi kelangsungan operasionalnya diantara faktor tersebut yaitu dapat menjadi kekuatan dan kelemahan konversi koperasi konvensional ke koperasi syariah itu sendiri diantaranya adalah:

a. Kekuatan (strength) konversi koperasi konvensional ke koperasi syariah di Kota Padang Panjang

1) Koperasi yang telah mempunyai status badan hukum;

2) Komitmen yang kuat pengurus koperasi untuk melakukan konversi ke syariah;

3) Pengurus koperasi yang memberikan pelayanan yang memuaskan kepada anggotanya;

4) Koperasi yang memiliki fasilitas yang memadai dalam pelaksanaan kegiatannya; dan

5) Koperasi telah melakukan sosialisasi tentang koperasi prinsip syariah kepada anggotanya.

b. Kelemahan (weaknesses) konversi koperasi konvensional ke koperasi syariah di

Kota Padang Panjang

1) Masih kurangnya kualitas sumber daya manusia koperasi yang memahami tentang pola pembiayaan syariah; 
2) Pelaksanaan operasional koperasi yang masih konvensional, belum memanfaatkan penggunaan teknologi informasi dan komunikasi;

3) Unit usaha koperasi yang masih terbatas pada usaha simpan pinjam; dan

4) Pemahaman anggota yang masih minim tentang prinsip syariah.

2. Faktor eksternal konversi koperasi konvensional ke koperasi syariah di Kota Padang Panjang

Faktor eksternal ini merupakan faktor yang berasal dari luar koperasi yang akan mempengaruhi kelangsungan hidupnya diantara faktor tersebut yaitu dapat menjadi peluang dan ancaman terhadap konversi koperasi konvensional ke koperasi syariah, diantaranya adalah:

a. Peluang (opportunities) konversi koperasi konvensional ke koperasi syariah di

Kota Padang Panjang

1) Adanya aturan hukum sebagai dasar dalam percepatan dan pengembangan koperasi syariah;

2) Kebijakan Pemerintah Kota Padang Panjang untuk melakukan percepatan dan pengembangan koperasi syariah;

3) Komitmen kuat Pemerintah Kota Padang Panjang dalam memfasilitasi dan mendorong pengembangan koperasi syariah;

4) Masyarakat yang kental akan adat basandi syarak syarak basandi kitabullah;

5) Pendampingan dari perguruan tinggi terhadap pengembangan koperasi syariah;

6) Tuntutan akan akses pembiayaan yang cepat, mudah, dan murah dari pelaku usaha; dan

7) Dukungan dari tokoh masyarakat dan alim ulama dalam pengembangan koperasi syariah.

b. Ancaman (threats) konversi koperasi konvensional ke koperasi syariah di Kota Padang Panjang

1) Ketatnya persaingan dengan lembaga keuangan lain khususnya lembaga keuangan bank;

2) Perkembangan yang sangat cepat dalam bidang teknologi informasi dan komunikasi;

3) Minimnya pemahaman masyarakat terhadap koperasi dengan prinsip syariah;

4) Lembaga perbankan mempunyai kekuatan modal yang cukup besar dalam penyaluran pembiayaan; dan

5) Masih kurangnya jumlah pengawas syariah yang memiliki sertifikat kompentensi MUI.

\section{Matrik SWOT}

Matrik SWOT dapat menggambarkan bagaimana peluang dan ancaman dari lingkungan eksternal pelaksanaan konversi koperasi konvensional ke koperasi syariah diantisipasi dengan kekuatan dan kelemahan yang dimilikinya. Matrik ini dapat menghasilkan empat set kemungkinan alternatif strategi. Hasil analisis matrik SWOT konversi koperasi konvensional ke koperasi syariah dapat penulis paparkan seperti gambar dibawah ini: 
Diagram 2. Analisis Matrik SWOT Konversi Koperasi Koperasi Konvensional Ke Koperasi Syariah

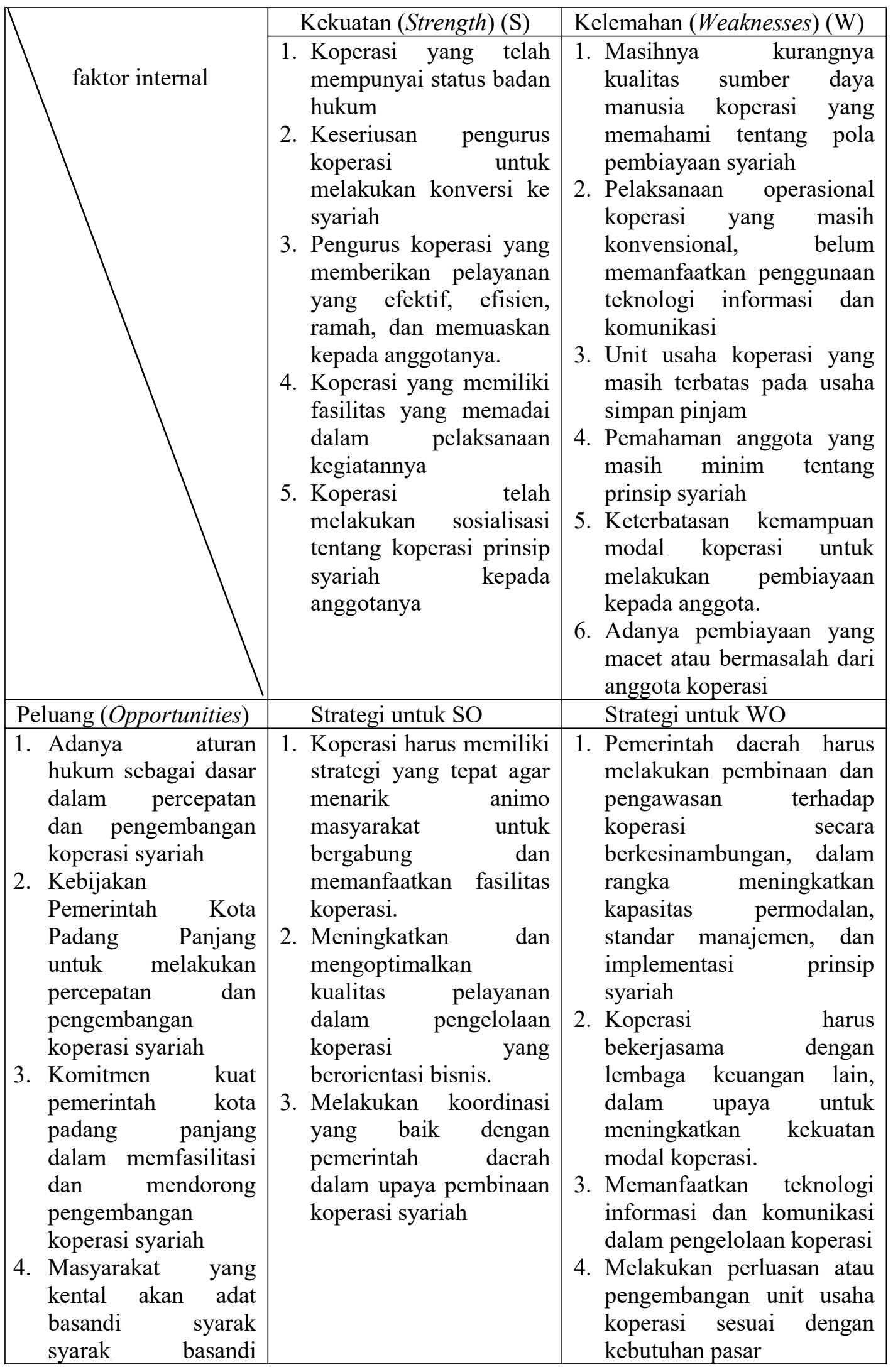




\begin{tabular}{|c|c|c|}
\hline $\begin{array}{l}\text { kitabullah } \\
\text { 5. Pendampingan dari } \\
\text { perguruan tinggi } \\
\text { terhadap } \\
\text { pengembangan } \\
\text { koperasi syariah } \\
\text { 6. Tuntutan akan akses } \\
\text { pembiayaan yang } \\
\text { cepat, mudah, dan } \\
\text { murah dari pelaku } \\
\text { usaha. } \\
\text { 7. Dukungan dari tokoh } \\
\text { masyarakat dan alim } \\
\text { ulama dalam } \\
\text { pengembangan } \\
\text { koperasi syariah. }\end{array}$ & & $\begin{array}{l}\text { 5. Secara berkala melakukan } \\
\text { audit atau pengawasan } \\
\text { internal oleh lembaga } \\
\text { independen } \\
\text { 6. Melakukan sosialisasi } \\
\text { kepada seluruh anggota } \\
\text { koperasi tentang prinsip } \\
\text { syariah. }\end{array}$ \\
\hline Ancaman (Threats) & Strategi untuk ST & Strategi untuk WT \\
\hline $\begin{array}{l}\text { 1. ketatnya persaingan } \\
\text { dengan lembaga } \\
\text { keuangan lain } \\
\text { khususnya lembaga } \\
\text { keuangan bank } \\
\text { 2. perkembangan yang } \\
\text { sangat cepat dalam } \\
\text { bidang teknologi } \\
\text { informasi komunikasi } \\
\text { 3. minimnya pemahaman } \\
\text { masyarakat terhadap } \\
\text { koperasi dengan } \\
\text { prinsip syariah } \\
\text { 4. lembaga perbankan } \\
\text { mempunyai kekuatan } \\
\text { modal yang cukup } \\
\text { besar dalam } \\
\text { penyaluran danaan } \\
\text { pembiayaan }\end{array}$ & 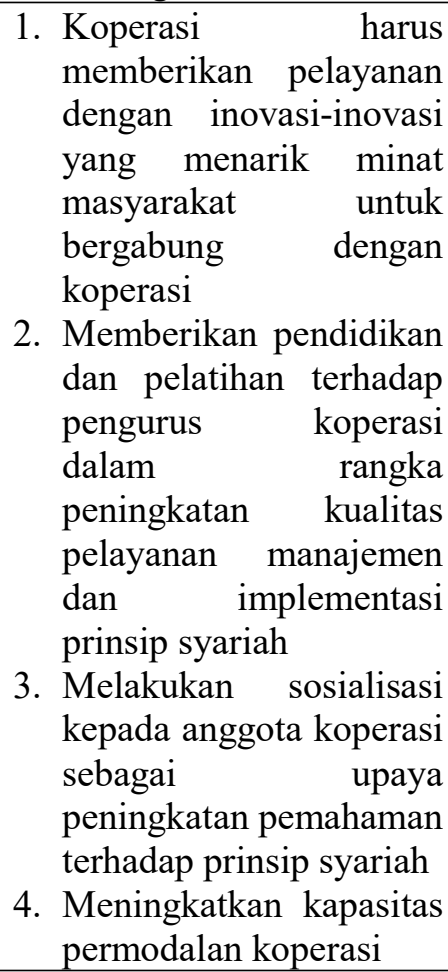 & 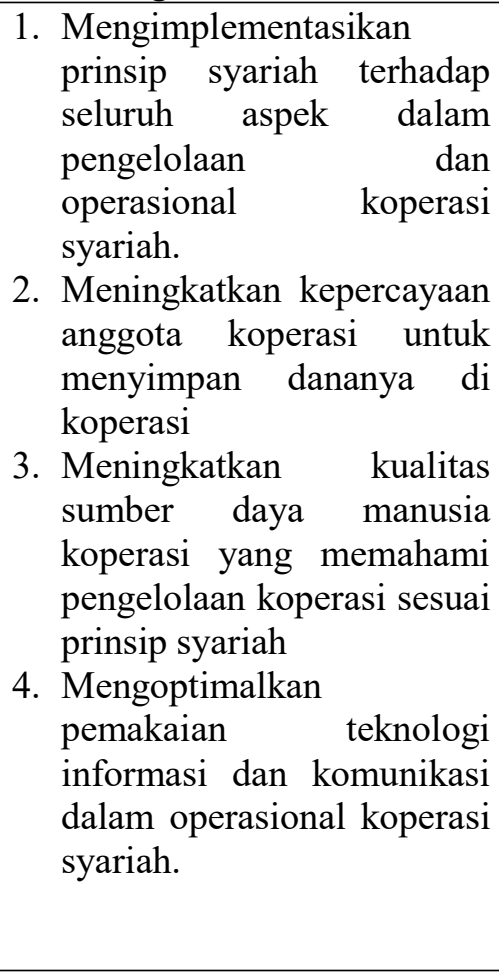 \\
\hline
\end{tabular}

Sumber: data diolah, 2021

\section{IFAS dan EFAS}

IFAS (internal strategic factors analysis summary) dan EFAS (external strategic factors summary) adalah faktor-faktor strategis internal dan eksternal perusahaan untuk diidentifikasi, suatu tabel IFAS dan EFAS disusun untuk merumuskan faktor-faktor strategis internal (kekuatan dan kelemahan) dan eksternal (peluang dan ancaman). Berikut adalah tabel IFAS dan EFAS konversi koperasi konvensional ke koperasi syariah, yang dilakukan dengan menyusun dan menghitung nilai bobot, rating, dan skor dengan teknik skala sebagai berikut: 
Tabel 3. IFAS (Internal Strategic Factors Analysis Summary)

Konversi Koperasi Konvensional Ke Koperasi Syariah

\begin{tabular}{|c|c|c|c|}
\hline Uraian & $\begin{array}{l}\text { Bobot } \\
(\mathrm{BN})\end{array}$ & $\begin{array}{l}\text { Ratting } \\
\text { (RN) }\end{array}$ & $\begin{array}{c}\text { Skor } \\
(\mathrm{BN} X \mathrm{RN})\end{array}$ \\
\hline \multicolumn{4}{|l|}{ 1. Kekuatan (strength) } \\
\hline $\begin{array}{l}\text { a. Koperasi yang telah mempunyai status badan } \\
\text { hukum }\end{array}$ & 0,11 & 4 & 0,44 \\
\hline $\begin{array}{l}\text { b. Keseriusan pengurus koperasi untuk melakukan } \\
\text { konversi ke syariah }\end{array}$ & 0,11 & 4 & 0,44 \\
\hline $\begin{array}{l}\text { c. Pengurus koperasi yang memberikan pelayanan } \\
\text { yang efektif, efisien, ramah, dan memuaskan } \\
\text { kepada anggotanya. }\end{array}$ & 0,11 & 4 & 0,44 \\
\hline $\begin{array}{l}\text { d. Koperasi yang memiliki fasilitas yang memadai } \\
\text { dalam pelaksanaan kegiatannya }\end{array}$ & 0,07 & 3 & 0,21 \\
\hline $\begin{array}{l}\text { e. Koperasi telah melakukan sosialisasi tentang } \\
\text { koperasi prinsip syariah kepada anggotanya }\end{array}$ & 0,09 & 3.5 & 0,31 \\
\hline $\begin{array}{l}\text { f. Koperasi memiliki sumber daya manusia yang } \\
\text { potensial untuk dikembangkan }\end{array}$ & 0,07 & 3.5 & 0,25 \\
\hline Jumlah & 0,56 & & 2,09 \\
\hline \multicolumn{4}{|l|}{ 2. Kelemahan (weaknesses) } \\
\hline $\begin{array}{l}\text { 1. Masihnya kurangnya kualitas sumber daya } \\
\text { manusia koperasi yang memahami tentang pola } \\
\text { pembiayaan syariah }\end{array}$ & 0,07 & 2 & 0,14 \\
\hline $\begin{array}{l}\text { 2. Pelaksanaan operasional koperasi yang masih } \\
\text { konvensional, belum memanfaatkan penggunaan } \\
\text { teknologi informasi dan komunikasi }\end{array}$ & 0,11 & 1 & 0,11 \\
\hline $\begin{array}{l}\text { 3. Unit usaha koperasi yang masih terbatas pada } \\
\text { usaha simpan pinjam }\end{array}$ & 0,11 & 1 & 0,11 \\
\hline $\begin{array}{l}\text { 4. Pemahaman anggota yang masih minim tentang } \\
\text { prinsip syariah }\end{array}$ & 0,07 & 3 & 0,21 \\
\hline $\begin{array}{l}\text { 5. Keterbatasan kemampuan modal koperasi untuk } \\
\text { melakukan pembiayaan kepada anggota }\end{array}$ & 0,04 & 3 & 0,12 \\
\hline $\begin{array}{l}\text { 6. Adanya pembiayaan yang macet atau bermasalah } \\
\text { dari anggota koperasi }\end{array}$ & 0,04 & 3 & 0,12 \\
\hline Jumlah & 0,44 & & 0,81 \\
\hline Jumlah $(\mathrm{S}+\mathrm{W})$ & 1 & & 2,98 \\
\hline
\end{tabular}

Sumber: data diolah, 2021.

Pada tabel di atas faktor-faktor kekuatan (strengths) mempunyai nilai skor 2,09 sedangkan faktor-faktor kelemahan (weaknesses) mempunyai nilai skor 0,81. Berarti pelaksanaan konversi koperasi konvensional ke koperasi syariah mempunyai kekuatan yang lebih besar dibandingkan dengan faktor kelemahan sehingga koperasi syariah di kota padang panjang memiliki kekuatan yang besar untuk pengembangannya. 
Tabel 4. EFAS (External Strategic Factors Summary) Konversi Koperasi Konvensional Ke Koperasi Syariah

\begin{tabular}{|c|c|c|c|}
\hline Uraian & $\begin{array}{l}\text { Bobot } \\
(\mathrm{BN})\end{array}$ & $\begin{array}{c}\text { Rating } \\
\text { (RN) }\end{array}$ & $\begin{array}{c}\text { Skor } \\
\text { (BN X RN) }\end{array}$ \\
\hline \multicolumn{4}{|l|}{ 1. Peluang (opportunities) } \\
\hline $\begin{array}{l}\text { a. Adanya aturan hukum sebagai dasar dalam } \\
\text { percepatan dan pengembangan koperasi syariah }\end{array}$ & 0,11 & 4 & 0,44 \\
\hline $\begin{array}{l}\text { b. Kebijakan Pemerintah Kota Padang Panjang } \\
\text { untuk melakukan percepatan dan pengembangan } \\
\text { koperasi syariah }\end{array}$ & 0,11 & 4 & 0,44 \\
\hline $\begin{array}{l}\text { c. Komitmen kuat pemerintah kota padang panjang } \\
\text { dalam memfasilitasi dan mendorong } \\
\text { pengembangan koperasi syariah }\end{array}$ & 0,11 & 4 & 0,44 \\
\hline $\begin{array}{l}\text { d. Masyarakat yang kental akan adat basandi syarak } \\
\text { syarak basandi kitabullah }\end{array}$ & 0,07 & 2 & 0,14 \\
\hline $\begin{array}{l}\text { e. Pendampingan dari perguruan tinggi terhadap } \\
\text { pengembangan koperasi syariah }\end{array}$ & 0,11 & 3 & 0,33 \\
\hline $\begin{array}{l}\text { f. Tuntutan akan akses pembiayaan yang cepat, } \\
\text { mudah, dan murah dari pelaku usaha. }\end{array}$ & 0,07 & 3 & 0,21 \\
\hline $\begin{array}{l}\text { g. Dukungan dari tokoh masyarakat dan alim ulama } \\
\text { dalam pengembangan koperasi syariah. }\end{array}$ & 0,04 & 2 & 0,08 \\
\hline Jumlah & 0,61 & & 2,08 \\
\hline \multicolumn{4}{|l|}{ 2. Ancaman (threats) } \\
\hline $\begin{array}{l}\text { a. Ketatnya persaingan dengan lembaga keuangan } \\
\text { lain khususnya lembaga keuangan bank }\end{array}$ & 0,12 & 1 & 0,12 \\
\hline $\begin{array}{l}\text { b. Perkembangan yang sangat cepat dalam bidang } \\
\text { teknologi informasi komunikasi }\end{array}$ & 0,11 & 1 & 0,11 \\
\hline $\begin{array}{l}\text { c. Minimnya pemahaman masyarakat terhadap } \\
\text { koperasi dengan prinsip syariah }\end{array}$ & 0,04 & 3 & 0,12 \\
\hline $\begin{array}{l}\text { d. Lembaga perbankan mempunyai kekuatan modal } \\
\text { yang cukup besar dalam penyaluran pembiayaan }\end{array}$ & 0,04 & 3 & 0,12 \\
\hline $\begin{array}{l}\text { e. Masih kurangnya jumlah pengawas syariah yang } \\
\text { memiliki sertifikat kompentensi mui }\end{array}$ & 0,11 & 2 & 0,22 \\
\hline Jumlah & 0,39 & & 0,69 \\
\hline Jumlah $(\mathrm{W}+\mathrm{T})$ & 1 & & 2,77 \\
\hline
\end{tabular}
sumber : data diolah, 2021.

Pada tabel di atas faktor-faktor peluang (opportunities) mempunyai nilai skor 2,08 sedangkan faktor-faktor ancaman (threats) mempunyai nilai skor 0,69. Berarti pelaksanaan konversi koperasi konvensional ke koperasi syariah mempunyai peluang yang lebih besar dibandingkan dengan faktor ancaman.

\section{PENUTUP}

Berdasarkan penelitian yang sudah dilaksanakan, maka penulis menyimpulkan bahwa pada kondisi internal, faktor-faktor kekuatan (strengths) mempunyai nilai skor 2,09 sedangkan faktor-faktor kelemahan (weaknesses) mempunyai nilai skor 0,81. Berarti pelaksanaan konversi koperasi konvensional ke koperasi syariah mempunyai kekuatan yang lebih besar dibandingkan dengan faktor kelemahan sehingga koperasi syariah di Kota Padang Panjang memiliki kekuatan yang besar untuk pengembangannya. Sedangkan pada 
kondisi eksternal, faktor-faktor peluang (opportunities) mempunyai nilai skor 2,08 sedangkan faktor-faktor ancaman (threats) mempunyai nilai skor 0,69. Berarti pelaksanaan konversi koperasi konvensional ke koperasi syariah mempunyai peluang yang lebih besar dibandingkan dengan faktor ancaman.

Pengurus koperasi yang melakukan proses transisi ke syariah harus meningkatkan kualitas sumber daya manusia yang memahami pengelolaan koperasi sesuai prinsip syariah. Hal tersebut dapat dilaksanakan melalui pendidikan dan pelatihan, dan penyelenggaraan rapat rutin internal koperasi untuk membahas hambatan yang terjadi di lapangan. Selain itu, pengurus koperasi harus memanfaatkan teknologi informasi dan komunikasi dalam pengelolaan koperasi dalam rangka efektifitas dan efisiensi operasional kegiatan koperasi serta peningkatan pelayanan kepada anggota koperasi.

Pemerintah Daerah harus melakukan pembinaan dan pengawasan terhadap koperasi secara berkesinambungan, dalam rangka meningkatkan kapasitas permodalan, standar manajemen, dan implementasi prinsip syariah. Untuk itu, Pemerintah Daerah harus mempunyai komitmen yang kuat untuk melaksanakan kebijakan pembinaan dan pengawasan koperasi, baik berupa pembinaan permodalan, sumber daya manusia koperasi, pelaksanaan monitoring, evaluasi dan pelaporan, pemeringkatan koperasi, dan penilaian KSP/USP.

\section{F. DAFTAR PUSTAKA}

Buchori, N. S., Harto, P. P., \& Wibowo, H. (2019). Manajemen Koperasi Syariah Teori Dan Praktik. Depok: Rajawali Pers.

Fahmi, I. (2013). Manajemen Pengambilan Keputusan Teori dan Praktek. Bandung: ALFABETA, cv.

Fitria, T. N. (2016). Kontribusi Ekonomi Islam Dalam Pembangunan Ekonomi Nasional. Jurnal Ilmiah Ekonomi Islam, 2(03), 29-40. https://doi.org/10.29040/jiei.v2i03.3

Iska, S. (2019). Sistem ekonomi syari'ah di sisi kelemahan sistem ekonomi sekuler di indonesia. Jurnal Studi Keislaman : El Hikam, 137, 223-230.

Nabhan, F. (2000). Sistem Ekonomi Islam. Terj. Muhadi Zainuddin. UII Pres. Yogyakarta.

Nofendy, D. (2020). Analisa Strategi Konversi PT. Bank Aceh Syariah. Universitas Islam Negeri Sumatera Utara.

Rangkuti, F. (1998). Analisis SWOT teknik membedah kasus bisnis. Gramedia Pustaka Utama.

Sofiana, T. (2014). Konstruksi Norma Hukum Koperasi Syariah Dalam Kerangka Sistem Hukum Koperasi Nasional. Jurnal Hukum Islam, 12(2), 135-151.

Sufyan, F. H. (2018). Menuju Lentera Merah: Gerakan Propagandis Komunis Di Serambi Mekah 1923-1949. UGM PRESS. 